\title{
Guidelines for Natural Food Conservation for the Community around the Upstream Forest of the Chi River Basin
}

\author{
Pramuk Srichaiwong ${ }^{1}$, Lagkhana Kwawjai ${ }^{1}$ \& Patarapong Kroeksakul ${ }^{2}$ \\ ${ }^{1}$ Faculty of Liberal arts and Science, Chaiyaphum Rajabhat University, Thailand \\ ${ }^{2}$ Faculty of Environmental culture and Ecotourism, Srinakharinwirot University, Thailand \\ Correspondence: Pramuk Srichaiwong, Faculty of Liberal arts and Science, Chaiyaphum Rajabhat University, \\ Thailand. Tel: 66-84-265-4985. E-mail: kekosakull@hotmail.com
}

Received: January 30, $2014 \quad$ Accepted: February 22, $2014 \quad$ Online Published: March 26, 2014
doi:10.5539/ass.v10n8p132
URL: http://dx.doi.org/10.5539/ass.v10n8p132

\begin{abstract}
The study of guideline for natural food conservation of communities around the upstream forest of the Chi river basin has aimed to find a way to cultivate the natural food plants of a community in the buffer zone between a national park and the community around and upstream forest in the Nongbuadang District, Chaiyaphum Province, Thailand. This study was phenomenological, with a, qualitative method used to collect data from four key informant (KI) groups; local wisdom (10 persons), government officials form Phukeaw National Park (two persons), village headmen (seven persons) and villagers using natural product in forest (40 persons). It was found that there are two patterns of natural food use for villagers from the forest; 1) consumption in the household; and 2) finding for sale in the local market. There are two levels of problems: 1) impact from government policy with national development relating to land use for increasing potential of agriculture production; and 2) behavior of villagers regarding resource use. However, the present government is mainly organized to conserve resources. Nevertheless, the guidelines of natural food conservation are created so the government must empower communities with villager participation, create cognizance in villagers around the forest, use local wisdom as a mechanism for transferring knowledge, set up a public network for learning and working including group responsibility, and create a pattern of demonstration plots.
\end{abstract}

Keywords: Chi river basin, Thailand, natural food management in forest

\section{Introduction}

Deforestation around the upstream of the Chi River basin was begun by villagers who wanted to increase their area to produce agriculture, responding to the government plan "The National Economic and Social Development Plan: Phase I" (1961-1966) (Government of Thailand, 1967). The plan proposed to develop the Isaan region (northeastern Thailand) producing cash crops such as cassava, kenaf, and sugarcane (Thongphan, 1993). The methods attempted to influence the agricultural practices of villagers who changed to inputting raw materials such as chemical pesticides or fertilizers and who also used hard technology such as tractors and backhoes to level land for plant production. That situation created pressure to increase the deforestation rate in the upstream forest of the Chi river basin. Deforestation later affected the environment by increasing soil erosion (Lorsirirat \& Maita, 2006), and decreasing wildlife habitats and natural food resources.

The forest is a food bank for communities around the forest, where 162 species of natural food plant products in Isaan (Sriphairot et al., 1994) were found, and according to Srichaiwong et al. (2014) about the biodiversity of natural food production in the upstream forest of the Chi river basin, there are 109 species including 25 species of tree, 14 species of shrubs and annual crops, 21 climber species, 22 species of wetland plants, 21 mushroom species, and 6 species of bamboo shoots. However, Klongtum et al. (1994) made a survey of the local market downstream from the Chi river basin and found 48 species of natural food plants comprising 30 land species, 14 water species, and 4 wetland species. Shirai and Rambo (2008) reported some natural food production distributed from Chaiyaphum Province to market in Khon Kaen and the value of natural food plant in the market totaled about 7.2 million baht/year (approximate $1 \mathrm{US}=33 \mathrm{baht}$ ). Thus, the upstream forest of the Chi River serves as the food bank for villagers within the community because most villagers use the forest for natural food production, since many people call the forest as "resource of local food." The report of the Communications Foundation (2008) presented an idea of local food systems describing a method of food production and 
distribution that it is geographically local rather than national and/or international.

Research questions include: does the community have natural food production management or not? And how does it do it? The aim of the research is to study guidelines for natural food conservation of the communities around the upstream forest of the Chi River basin. Nongbuadaeng district of Chaiyaphum Province was selected as a study area because it is the upstream forest zone of the Chi River basin and most villagers harvest food products from this forest.

\section{Literature Review}

\subsection{Physical and Land Use of the Area}

The Chi River basin is a zone in the Isaan region of Thailand (northeastern Thailand). The Chi River Basin has a rise in the Petchabun range. Its area is about 4,913,192 hectares $(49,131.92$ square kilometers) or $29 \%$ of the Isaan region, and the topography comprises high mountain ranges with the Phupan range in the north and east region, and the Dongphayayen range in the west region (Srichaiwong, 2014), so it covers all 14 provinces in the region. Kuntiyawichai (2012) reported the Chi River basin is located in the northeast of Thailand. The total area is 4.9 million ha with a population of 6.6 million people. It is located in the tropical monsoon region. The annual rainfall varies from 1,000-1,200 mm/year. The main river is the Chi River, which is the longest river in Thailand with a total length of $946 \mathrm{~km}$. The physical characteristics of the Chi River Basin vary significantly, including steep topography in the upstream areas and flat low-lying areas, i.e., broad flat floodplains at the downstream part, especially near the confluence with the Mun River, a major tributary of the Mekong River. Within the context of demographic dynamics, the population growth rate of the Chi River basin has increased to approximately $0.6 \%$ per year since 1993 . Most of the growth has occurred in rural areas, where about $61 \%$ of the people live. All of these effects have important implications for land use dynamics, which directly affect land demand and utilization. Presently, the majority of the river basin population is engaged in agriculture on the $60 \%$ of arable land where $41 \%$ is used for rice paddy fields. The remaining area is forest $(31 \%)$, urban $(2.9 \%)$, water bodies (2.5\%), and others (3.5\%). The Land Development Department (2009) reported the basin land use can be divided into seven parts: paddy fields (40.86\%); agronomy (21.01\%); forest (20.48)' other, such as a community area or water body $(13.24 \%)$; orchards and trees (3.34\%); other agriculture area, including livestock and aquaculture $(0.55 \%)$; and vegetables $(0.11 \%)$.

\subsection{Sources of Natural Food}

A study by Somnasang et al. (1988) about the role of natural food in northeast Thailand found the principal sources of natural food were the nearby forest, at least in areas where population pressure is less and some forest still remains. Foods from the forest include vegetables, mushrooms, frogs, toads, birds, lizards, rats, snakes and insects, as well as larger animals. Production is highest in the rainy season. Hunting and gathering in the forest are often combined with other activities that use the forest, such as fuel wood gathering, so the report presented the forest is important to natural food systems. Similarly, Dungjai et al. (2013) reported the forest is a source of natural food for villagers living in communities around mangrove forests in Stun Province in southern Thailand.

\subsection{Natural Food Management in Forest}

Natural food management in the forest is under the concept of forest management because its production is from the forest. Moulton (2008) studied traditional natural resource use and development in northeast Thailand, and reported that villagers use production from natural resources. The government controls and manages the resource, but villagers living around the forest know how to use natural resources. However, Chaiypha et al. (2012) studied payment for an ecosystem service concept from up-and downstream zones. They made a case study of Thapong Village, Nongbaurawe sub-district, Chaiyaphum Province and Phonoi villages, Sansuk sub-district, Phanompai district, Roi et Province, and indicated that this concept was unclear to the community and its organizations. Villagers had difficulty relating to the concept of paying for a superintendent for the ecosystem service. The issue faced by people in the up-and downstream zones suggests that they still hold a narrow perception of the concept. In the studies presented about the gap of natural management concept of community forest in Thailand will most likely fail if they use it as an instrument of forest politics in one category with commercial afforestation or the establishment of protected areas. However, the instrument of forest management form government officer is difficult to livelihood system of villagers live in around the forest, because the villagers have a perception that natural food production in the forest is public production.

\section{Methodology}

This is a phenomenal study of guidelines for natural food conservation of the community around the upstream forest of the Chi River basin. The qualitative methodology was mainly used because the local people were relied 
on to gather the local data, which significantly focused on natural food product utilization and the pattern of using natural food from the upstream forest of the Chi River basin.

\subsection{Study Site}

The Nongbuadaeng District (Figure 1) is one of 16 districts of Chaiyaphum province, an area characterized by land about 300-650 meters above sea level and mountains as high as 1,020 meters above sea level. The Nongbuadaeng District covers 2,215.5 square kilometers (221,550 hectares) with a population of 98,067 in 16,789 households. Villagers live mainly in the agricultural sectors, farming paddy fields and cash crops such as sugar cane, cassava, kenaf, and Para rubber. Almost people in the district are Buddhist, and they use the Isaan language for communication. Isaan is the collective name for dialects of the Lao language and is spoken by approximately 20 million people (Kroeksakul et al., 2011).

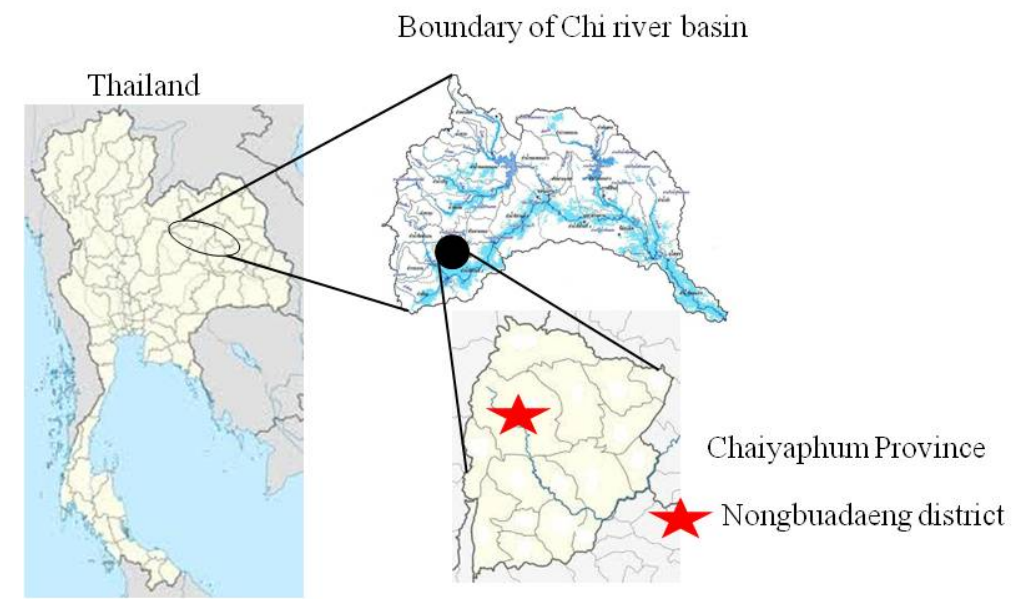

Figure 1. Study site

\subsection{Data Collection}

1) Secondary data were collected by using statistical data from the government, such as National Rural Development Data System (NRD Data System) and maps from a freeware program.

2) Primary data were collected from main key informant interviews, such as the village senior and village headman. All of the information will be checked via a group interview. The tools for corrected data were applied from rapid rural appraisal (RRA), such as a field notes, records, and semi-structured interviews (SSI) (Simaraks \& Suphatera, 1987).

\subsection{The Key Informant}

1) 10 local wisdom who use natural food products from upstream of the Chi River basin

2) Two government officials from Tard Thon National Park

3) Seven village headmen

4) 40 villagers who collect production from upstream of the Chi River basin forest

\subsection{Conceptual Framework}

This is a phenomenological study based on the research questions, does the community have natural food production management or not? And how does it do it? The answer to these research questions was connected with the villager situation of forest utilization in communities, as well as the consumers, producers, and the capacity of natural resources. However, a villager is a user of a product and they have knowledge of natural food production in the forest and the situation of natural food production, so the information it's situation natural food production in upstream forest of Chi river basin. The collected data was classified for content analysis and set up by theme data category before guideline setting. The conceptual framework is shown in Figure 2. 


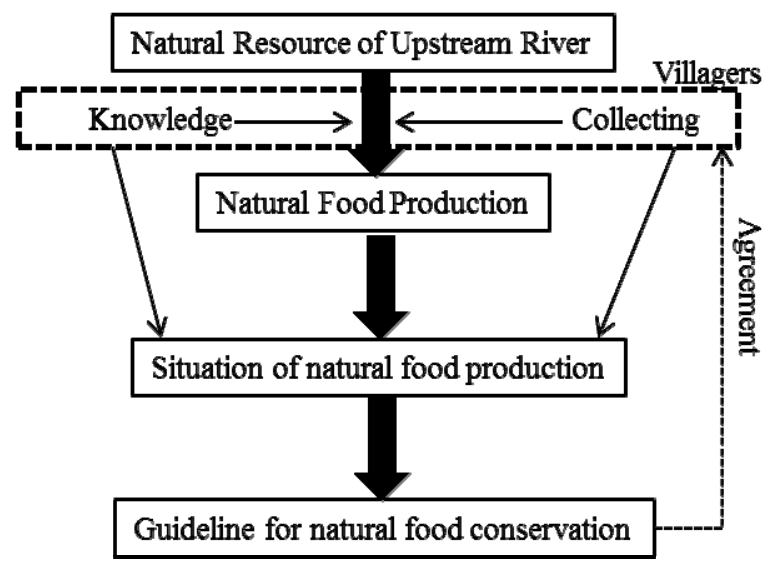

Figure 2. Conceptual framework

\section{Results and Discussion}

\subsection{The Problem of Upstream Forest at Present}

The main upstream forest was deforested 10 years ago to increase available agricultural area. The problem has been solved in the present day because the government has clearly determined the boundary of the national park and has laws to protect the area. However, the problem of villagers around the upstream forest is the volume of natural production decreasing because of natural production overuse of villagers in communities around the upstream forest and also from other communities.

\subsection{Situation of Natural Food Production from the Upstream Forest}

Traditionally, the forests have served multiple human uses in addition to providing sites for swidden farming and agricultural conversion. The forests have continuously served multiple human uses, providing sites for farming and agricultural conversion. They are the principal sources of timber and other construction material for village houses. Firewood and charcoal are collected to meet household needs and as a source of cash for families with insufficient farmland. Wildlife is hunted and forest plants are collected as food and medicine (Rambo, 1991). However, the forest in the perception of villagers is a public area, because everyone can use available resources.

In 1964, the government promoted the National Economic and Social Development Plan: Phase I, a strategy to develop villagers' economic plant production. However, the villagers have an increasing area to produce cash crops such as sugarcane, cassava, and corn for animal feed. The changing of land use decreased the species of natural food plants such as rattan (Calamus viminalis), Pakwanpha (Melietha suavis Pierre), Pak srab (Adenia viridiflora Craib). Food from natural products has declined, according to the values and needs of consumers. However, the high price of natural food plants attracts villagers from other communities to come to this area to collect the products. The villagers living inside and outside the community in the upstream forest of the Chi River basin collected natural food products all year, so it affected the natural production rate and degraded the forest environment. The government has many projects to improve the forest but it is not enough for villagers' natural resource use. This supports the report of Delang (2002) who maintains that the decadent forest cannot compensate for old natural resources, while Martin et al. (2002) believes that even if reforestation continues for more than 10 years, it cannot make reparation for plant species and habitat.

\subsection{Pattern of Villagers' Natural Food Collecting}

There are two reasons for villagers collecting natural food products from the upstream forest:

1) Most villagers live in communities around the forest and collect natural food products. From the buffer zone between the community (community forest) and the national park, a group of about 2-5 villagers collecting natural products within 2-4 hours. The villagers they think that collecting natural products is an activity for finding food to support their family, not only saving money but also relaxing. The villagers will pick enough natural food products for their family to consume.

2) Collecting natural food products for sale, a community group will collect natural food products to support dealers in local markets or middlemen who collect natural food products from villagers for transport to markets all over the Isaan region. Shirai and Rambo (2008) concluded that almost natural food products in the Khon 
Kaen market are imported from the Nongboudang District in Chaiyaphum Province. However, some villagers in the group will also go to other places in the Isaan region such as Pha Phuphan (Phuphan National Park) in the Sakhonnakhon and Kalasin Provinces. The collected main natural food products included mushrooms, vegetables, and bamboo shoots, which villagers will take all day to collect.

\subsection{Economic Side}

1) The importance of natural food production is the household food dependency system; because the products are being collected by villagers is a main component in their menu. Villagers will go to the forest to collect mushrooms (weighing around 0.8-2 kilogram) and also yanang or bamboo grass (Tiliacora triandra). This product can make about 4 cups of soup (sale price in restaurant about 80 baht per cup) for a total value of around 320 baht (approximately US \$10). Villagers can collect natural food products from the forest about 60 times a year, so the value of food production from the upstream forest of the Chi River basin is about 19,200 baht per year (approximately US \$600). However, the report by the Secretary of the Convention on Biological Diversity (2001) called natural foods from the forest valuable because they are clean and free from chemicals and also helpful in the community food security situation (Food Agriculture Organization [FAO.], 2013; Ogden, 1996)

2) Villagers in communities will send a group of 5-15 persons to find natural food products in the upstream forest of the Chi River basin. However, there are many groups from other areas looking for natural food product. They will rent a pickup truck holding 5-7 persons, costing 50-200 baht/head/time (approximately US \$1.50-6.25) or a six-wheel truck holding 5-15 persons. They earn about 500-1,000 baht per hour from natural food products (approximately US \$15.60-31.25), so if villagers can find natural food product 60 times per year, they will earn about 30,000-60,000 baht per year (approximately US \$936-1,875). However Ogden (1996) believes production from the forest over food, drug and energy could create income for villagers in communities. Duangjai et al. (2013) argued that communities have natural sovereignty, so there is much to be considered in user habits.

\subsection{The Knowledge Side}

1) Villagers know a great deal about the location of natural food plants and transfer knowledge to new generations from direct experience, and this is supported by the report of Johnson et al. (2013) that geography is specific to the distribution of natural food.

2) Villagers know a great deal about types of food plants, so they can tell the difference between safe and toxic mushrooms as well as where the plant grows in the forest. Villagers received knowledge from direct leaning, discussed by Charnley et al. (2008) that the village can provide food products as natural resources for communities near the forest. Specific knowledge is part of the community.

3) Villagers know the correct time to look for natural food products. For example, they go into the forest to collect mushrooms from September to October; Pakwanpha (Melietha suavis Pierre) can be collected from March to May. Villagers directly learn from the previous generation. Arnold and Falconer (1991) studied the socio-economic aspects of food security and forest of household, and found that income and value of provident food in the community changes seasonally.

\subsection{Current Forest Management}

Current forest management it's classify were 2 groups;

1) According to the National Park Act of 1961, section 16, villagers cannot collect natural products from a national park area. However, the social side is difficult to control because the system of natural food product collecting is important to the livelihood of villagers in communities around the forest (Sheet, 2011). The Tad Thon National Park set up the "Protected Area Committee Tad Ton National Park (PAC)," including 34 committees consisting of government officials, community headmen, and non-government organizations to promote the benefit of forest conservation. However, the officials of the Tad Thon organization still use the National Park Act in forest management.

2) There is a forest conservation group in every community, but they are not always effective for two reasons. First, villagers will always work to support their family, and forest management is a popular pastime. Second, the village's volunteers to support government officials but they do not authorize managing resources in the community forest.

In the forest management in area at present, villagers are users and government officers are protectors. The effect is that it is difficult for work together. However, gap between government and villager occurs because of the function and condition of organization in forest management. 


\subsection{Guidelines for Natural Food Plant Conservation}

Information collected by brainstorming for developing guidelines for natural food plant conservation, defined as sustainable management under the limitation of natural resources.

1) Empowerment and Participation of Villagers

This study found the main benefit of the upstream forest is as a food bank. Villagers understand natural resources and zones of natural food plants, but they cannot manage those resources even if they have conservation groups because of the lack of authority to manage those resources. However, empowerment and participation of villagers are important to the natural conservation process because villagers are users and direct stakeholders in resources.

The government must increase or distribute authority to villagers or communities concerning natural resources under National Park Act of 1961 and integrate a network of communities around the upstream forest for monitoring the natural resource situation and use that resource.

\section{2) Cognizance}

The general perception of villagers about natural resources is there are a plenty of natural food products in the upstream forest of the Chi River basin, so they use resources too heavily. Considering the spatial extent of the resource, timing of product collection, and distance to collecting natural food products in the upstream forest, use has increased when compared to 10 years ago. Villagers understanding that resources are limited are important. Young persons can understand this concept by some activity such as study trip or a natural camp. However, this process must join with multi-level networks such as the Tad Tond National Park supporting officers to transfer information about natural conservation and local wisdom lectures to practice collecting natural food products from the forest and preserving this natural resource while supporting the budget from the local government. This goal makes villagers appreciate the conservation of native vegetation planting. The ecosystem and maintaining a sustainable community.

3) Elevating Local knowledge in the Community

This study found villagers have knowledge about herbs and using plants for medicine, natural food plants, and the propagation process of natural plant species. However, the knowledge of villagers never been expanded to explicit knowledge because the local leaders also understand to their knowledge is outdated and are ashamed to change this for the next generation. Elevating local community knowledge means appreciating local wisdom and using those sages as a way to transfer knowledge to future generations.

\section{4) Conserving Natural Food Plant Areas}

At present, villagers understand the effect of deforestation to increase the monoculture production area, and the direct impact on natural food sources is limited. What should cause concern is the new generation who is not interested in natural foods because of the changes in consumer behavior, so all households should have an area for growing vegetables in the back yard, or the community should use a public area to conserve natural food plants.

\section{5) Establishing Demonstration Plots}

This study found that the types of vegetation to be planted in the demonstration of the Learning Center should be diverse and similar to the forest, including perennial trees, herbaceous perennial shrubs, or vine crops in the water. The established demonstration plots can produce natural food plants such as:

a) Perennial trees, such as Careya sphaerica Roxb., Gratoxylum formosum (Jack) Dyer, Milletia sp.

b) Shrubs and annual crops, such as Sauropus androgynous, Emilia sonchifolia (L.) DC.

c) Climbers, such as Monordica charantia Linn., Telosma minor Craib, Aganonerion polymorphum Pierre ex Spire.

d) Wetland plants, such as Lasia spinosa Thw., Limnocharis flava Buch., Nymphaea lotus Linn.var.Pubesens Hook.f.

A demonstration site should be built in a public area where everybody could visit and also care for the garden. The area should be suitable for setting the establishing demonstration plots and should be located in public areas in the community such as temples, schools, health centers or the local government. 


\section{Conclusion}

The study is about guidelines for natural food conservation in communities around the upstream forests of the Chi River basin. The first priority is to understand the dynamics of the area's situation and the benefits of natural food plants in the upstream forest. The information was gathered from four key information groups: local savants; national park officials; community headmen; and product collectors from the upstream forest. In this study found to the villager live in community around upstream forest of Chi river basin has perceive with using managing natural food production but they don't direction to management for conservation with natural food production in the forest. There are two patterns of collected food products from the natural forest; the first is used for consumption in the household, and the second for selling. Both patterns are important to household economics. This study gathered knowledge about natural resources using the physical aspects of forests, botanical aspects of plants, and also distribution of natural food plants in the upstream forest of the Chi River basin. The two groups in forest management at present are: 1) government management under the National Park Act of 1961, where officials try to participate with communities around the forest by appointing the Protected Area Committee from Tad Ton National Park (PAC); and 2) creating conservation groups in communities. Guidelines for natural food plant conservation must include: 1) empowerment and participation of villagers; 2) beginning a process to transform villager cognizance; 3) elevating the knowledge of local wisdom in the community; 4) specifying boundaries of conserving natural food plant areas and volumes for collecting; and 5) establishing demonstration plots in public areas such as temples or schools. This study offers guidelines to present to decision-makers at multiple levels such as community level and also the regional government to develop a strategic policy to conserve natural food products in the upstream forest in the Chi River basin.

\section{Acknowledgments}

This research project was financially supported by the Office of the Higher Education Commission (OHEC) in 2012. The authors and researchers would like to thank all of the villagers and assistants for their contributions to the interview processes. In addition, the assistant researcher wishes to thank Dr. Prachakorn Chaiyakot, who assisted in editing this report.

\section{References}

Arnold, J. E. M., \& Falconer, J. (1991). Household food security and forestry an analysis of socio-economic issues. Food and Agriculture Organization of the United Nations. Retrieved from http://www.fao.org/docrep/006/t6125e/T6125E00.HTM\#TopOfPage

Brenner, V., Buergin, R., Kessler, C., Pye, O., Schwarzmeier, R., \& Sprung, D. R. (1999). Thailand's community forest bill: U-turn or roundabout in forest policy? SEFUT Working paper No.3, Albert-Ludwigs-Universitüt Freiburg. Retrieved from http://www.sefut.uni-freiburg.de/pdf/WP_3.pdf

Chaipha, W., Sakolnakorn, T. P. N., \& Kroeksakul, P. (2011). The Study of Payment for an Ecosystem Service Concept: Case Study of Thapong Village, Nongbaurawe Sub-district, Chaiyaphum Province and Phonoi Villages, Sansuk Sub-district, Phanompai District, Roi Et Province. Naresuan University Journal, 20(1), 41-47.

Charnley, A. S., Fischer, P., \& Jones, T. E. (2008). Traditional and local ecological knowledge about forest biodiversity in the Pacific Northwest. United States Department of Agriculture Forest Service, Pacific Northwest Research Station, General Technical Report PNW-GTR-751. Retrieved from http://www.arlis.org/docs/vol1/A/233598591.pdf

Communications Foundation. (2008). Local \& regional food systems. Food program. Retrieved August 11, 2013, from http://www.sustainableable.org/254/local-regional-food-systems

Delang, O. C. (2002). Deforestation in Northern Thailand: The result of Hmong farming practices or Thai development strategies? Society and Natural Resources, 15(6), 483-501. http://dx.doi.org/10.1080/08941920290069137

Duangjai, W., Ngamniyom, A., Silaprasit, K., \& Kroeksakul. (2013). The guideline development for sustainable livelihood indicators of village marginal mangrove forest in the Stun province, Thailand. Asian Social Science, 9(9), 123-130. http://dx.doi.org/10.5539/ass.v9n9p123

Food and Agriculture Organization (FAO.). (2013). Forests, food security and gender: Linkages, disparities and priorities for action 1. Background paper for the International Conference on Forests for Food Security and Nutrition, FAO, Rome, 13-15 May, 2013. Retrieved from http://www.fao.org/forestry/37071-07fcc88f7f1162db37cfea44e99b9f1c4.pdf

Government of Thailand. (1967). Evaluation of the first six-year plan 1961-1966. The National Economic and Development Board Office of The Prime Minister, 1967. 
Johnson, R., Aussenberg, A. R., \& Cowan, T. (2013). The role of local food systems in U.S. farm policy specialist in agricultural policy. Congressional Research Service 7-5700 www.crs.gov R42155. Retrieved from http://www.fas.org/sgp/crs/misc/R42155.pdf

Klongtum, P., Taveesarn, T., Sungsen, W., Kongnonnork, C., Janthanam, T., Yongyut, W., \& Makkhanan, P. (1994). A guideline of vegetable native recover in wet land: Case studies Kudpheng wet land in Yangkham sub-district, Phonsai district, Roi et province, Thailand. Full report of Local Research. Thailand Thailand Research Fund (TRF).

Kroeksakul, P., Sakolnakorn, T. P. N., \& Naipinit, A. (2011). The economic and social effects of farmers growing para rubber in northeast Thailand: A case study of Sapsomboon village, Dun Sad sub-district, Kranoun district, Khon Kaen province. Journal of Business Case Studies, 7(1), 113-118.

Kuntiyawichai, K. (2012). Interactions between land use and flood management in the Chi river basin. Thesis for the degree of doctor, Academic Board of Wageningen University and the Academic Board of the UNESCO-IHE Institute for Water Education.

Land Development Department. (2009). Report of land use. Thailand. Retrieved from http://olp101.ldd.go.th/web_plan1/report/53/53_2.doc

Lorsirirat, K., \& Maita, H. (2006). Soil Erosion Problems In Northeast Thailand: A Case Study from the View of Agricultural Development in a Rural Community Near Khon Kaen. Disaster Mitigation of Debris Flows, Slope Failures and Landslides. By Universal Academy Press, Inc. Tokyo, Japan (pp. 675-686). Retrieved from http://www.interpraevent.at/palm-cms/upload_files/Publikationen/Tagungsbeitraege/2006_2_675.pdf

Martin, J. P., Browne-Clayton, S., \& McWilliams, E. (2002). A results-based system for regulating reforestation obligation. The Forestry Chronicle, 78(4), 492-498. http://dx.doi.org/10.5558/tfc78492-4

Moulton, C. (2008). Traditional natural resource use and development in northeast Thailand. Senior Honors Projects (p. 107). Retrieved from http://digitalcommons.uri.edu/srhonorsprog/107

Ogden, L. C. (1996). Considering nutrition in National Forestry Programmes, Formulation, implementation and revision of national forest programmes. Food and Nutrition division nutrition and programmes service, Food and Agriculture Organization of United Nation. Retrieved from http://www.fao.org/docrep/w2167e/w2167e00.htm\#TopOfPage

Rambo, T. (1991). The human ecology of rural resource management in northeast Thailand. Farming Systems Research Project, Faculty of Agriculture, Khon Kaen University, Thailand.

Secretary of the Convention on Biological Diversity. (2001). The value of forest ecosystems. Montreal, SCBD (CBD Technical Series No. 4, p. 67). Retrieved from http://www.cbd.int/doc/publications/cbd-ts-04.pdf

Sheet, M. (2011). Implications of land deals to livelihood security and natural resource management in Benshanguel Gumuz Regional State, Ethiopia. Paper presented at the International Conference on Global Land Grabbing (pp. 6-8). Retrieved http://www.iss.nl/fileadmin/ASSETS/iss/Documents/Conference_papers/LDPI/11_Maru_Shete.pdf

Shirai, Y., \& Rambo, A. T. (2008). The economic value of edible wild and semi-domesticated species sold in an urban market in Khon Kaen municipality in Northeast Thailand. Khon Kean Agriculture Journal, 36(1), 69-78.

Simaraks, S., \& Suphatera, S. (Eds.). (1987). Rapid rural appraisal manual. Framing system project, Khon Kaen University, Thailand.

Somnasang, P., Rathakette, P., \& Rathanapanya, S. (1988). Chapter five: The role of natural foods in Northeast Thailand. In W. G. Lovelace, S. Subhadhira, \& S. Simarak (Eds.), Rapid rural appraisal in Northeast Thailand: Case studies, KKU-FORD rural systems research project, Khon Kaen University (pp. 78-99).

Srichaiwong, P., Kwewjai, L., \& Kroeksakul, P. (2014). A study on the biodiversity of natural food production to support community upstream of Chi basin, Thailand. Asian Social Science, 10(2), 145-156.

Sriphairot, P., Mekphanorphat, T., \& Sriwirot, N. (1994). A studies Nutrition of local plant and vegetable of support villagers in Isaan region. Thailand, Mahasarakham University.

Thongphan, S. (1993). Agriculture policy. Odeonstore, Bangkok, Thailand.

\section{Copyrights}

Copyright for this article is retained by the author(s), with first publication rights granted to the journal.

This is an open-access article distributed under the terms and conditions of the Creative Commons Attribution license (http://creativecommons.org/licenses/by/3.0/). 